\title{
主桁損傷を受けた2主桁橋の 残存耐カに関する考察
}

\author{
橘 吉宏 $^{1} \cdot$ 辻角 学 $^{2} \cdot$ 越後 滋 $^{3} \cdot$ 高橋昭一 $^{4} \cdot$ 三木千壽 5 \\ '正会員 博士(工学) 川田工業（株）橋梁事業部東京設計部（广⿳114-8562 東京都北区滝野川 1-3-11） \\ ${ }^{2}$ 正会員 川田工業 (株) 橋梁事業部新事業企画室 （广 114-8562 東京都北区滝野川 1-3-11） \\ ${ }^{3}$ 正会員 博士(工学) 川田工業（株）技術開発本部（产 114-8562 東京都北区滝野川1-3-11） \\ ${ }^{4}$ 日本道路公団 静岡建設局富士工事事務所 (T 417-0061 静岡県富士市伝法字大原 170-1) \\ 5フェロー 工博 東京工業大学教授 工学部土木工学科 (T 152-0033 東京都目黒区大岡山 2-12-1)
}

\begin{abstract}
2 主析橋は, 片方の主析に損傷を受けたときに落橋の危険性がある, すなわち, リダンダンシーがない構 造であると考えられ易い.しかしながらこのような考え方がある一方で, 2 主析橋は主桁損傷後の残存耐力 を持ち得るとの報告がアメリカであり，2主桁橋の残存耐力については整理されていないのが現状であると 言える.そこで本研究は, 損傷の程度による挙動変化の把握や崩壊機構の解明を試みることを目的として, 1/ 2スケール模型の主析に損傷を与え, 載荷試験を実施した結果を報告し, 加えて, 載荷試験により解明された 崩壊機構に基づき, 実橋の 2 主标橋における安全性の評価を行うために実施した解析的な検討結果を報告す るものである.
\end{abstract}

Key Words : redundancy, two-girder bridges, loading test, load carrying capacity, FEM

\section{1.はじめに}

2 主桁橋は, 従来の多主桁橋に比べ, 鋼重, 部材数, 材片数, 溶接延長, 塗装面積が低減されることから, 製 作および施工時の合理化を図ることができ, 最近, そ の経済性から再び脚光を浴びている橋梁形式である!。

我が国でも昭和 30 年代後半から昭和 40 年代前半に かけて経済性に主眼を置いた少数主析橋が盛んに建設 されたが, 昭和 40 年代に過積載を含めた交通量の増大 と R C 床版の鉄筋量不足が原因と考えられる床版損傷 が顕在化し, 床版曲げモーメントの低減や床版補修の 容易さ等の理由から昭和50年代前後から多主桁で非合 成への採用と向かった.これはP C床版も適用されて いる連続合成 2 主析橋が一般的なヨーロッパとは逆の 傾向である. 一方, アメリカでは多主桁橋が主流であ り，2 主桁橋も建設されているが, ゲルバーヒンジ部 の損傷から落橋に至る事故が発生しており，2主析橋 のリダンダンシィが議論されているようである21.

アメリカの場合と同様に, 2 主桁橋を採用するにあ たって懸念されてきた課題の一つが, 2 主析橋の主桁 損傷後における安全性の問題である。議論の中には 「一方の主析に何らかの損傷が生じた 2 主析橋は落橋の 危険性があり, 点検や維持管理を十分に行うことがで
きないならば採用すべきではない」という意見もあれ ば,「アーチやトラスの主構と同様に主桁を取り扱い, 疲労に配慮した設計を行えば,危険性を指摘すること 自体が無意味である」との意見もある.

「落橋の危険性がある」と判断されるのは, 損傷を受 けた 2 主桁橋の状態を設計時の $1-0$ 法や平面格子解 析モデルの延長で考えれば,構造として成り立たたな いためであるが,この評価は鋼格子桁と床版の相互作 用を無視しているため, 正しい評価とは言えない. 損 傷を受けた 2 主桁橋の挙動については, アメリカで 1993年に 2 本主桁の実橋を対象として, 主桁の一部を ガス切断した後に載荷試験を実施した例が報告されて (る2).この報告では, フランジとウエブ切断後もすぐ には落橋には結びつかず, 車両載荷時には切断部を補 うように主桁, 縦桁, 横桁, 床版での立体的な挙動を 示すことが報告されている.しかし, 構造物としての 安全性の評価については, 実橋で終局的な崩壊状態を 確かめることができなかったことから課題であると述 ベるにとどまっている.

この報告から, 2 主析橋がすぐには落橋しないとの 安心感は得られるものの, 対象とした橋梁は縦析およ び下横構が配置されており,準閉断面桁として挙動す るため, わが国の「ホロナイ川橋」3),4) (日本道路公団・ 
北海道縦貫自動車道)に代表されるような下横構を省 略した 2 主桁橋に, 必ずしもそのままあてはまるとは 言えない.

このように, 2 主析橋の安全性に対する考え方につ いては整理されていないのが現状であり, 2 主桁橋の 安全性を評価するにあたり, まず, 損傷の程度による 挙動の変化や崩壊機構を解明することが必要であると 考えられた.

そこで本研究は, 損傷の程度による挙動変化の把握 や崩壊機構の解明を試みること,および解明された崩 壊機構に基づいて 2 主桁橋の安全性の評価を行うこと を目的に,「ホロナイ川橋」の設計検討時に製作した1/ 2スケール模型(5を利用して, 主桁に損傷を与え載荷試 験を実施し, F EMによる解析的な検討を行った結果 を報告するものである. なお, 本文で対象とする 2 主 桁橋は, 上述した「ホロナイ川橋」に代表される P C 床版を有し下横構を省略した 2 主析橋である.「ホロナ イ川橋」は, 鋼析が鉛直荷重に対しては非合成桁とし て設計されているが, 地震時や風荷重に対しては床版 剛性を期待した設計を行っている6). よって鋼桁と床 版とは合成が保証されており, 床版は半永久的な構造 部材として耐久性が十分に確保されている橋梁である.

\section{2. 試験概要}

\section{(1) 試験体の概要}

試験体には,「ホロナイ川橋」の設計検討時に疲労試 験を実施するために製作した, 1/2スケール模型を用い た. 表 -1 および図 -1 に試験体の概要図, 諸元をそれ ぞれ示す.

本試験体は疲労試験を想定して設計しており, 片側 主桁中央に80tf(784kN)の荷重振幅で試験体が合成挙動 を示すと仮定して下フランジに $900 \mathrm{kgf} / \mathrm{cm}^{2}\left(88.3 \mathrm{~N} / \mathrm{mm}^{2}\right)$ 程度の応力振幅となるように設計したものである.こ の $900 \mathrm{kgf} / \mathrm{cm}^{2}\left(88.3 \mathrm{~N} / \mathrm{mm}^{2}\right)$ は, ホロナイ川橋において活 荷重載荷時の下フランジに発生する応カレベル(非合 成桁として）に相当する.

$\mathrm{PC}$ 床版は 1 方向 P C版であり, 橋軸直角方向にプ レストレスが導入されており, 橋軸方向は R C 構造で ある.この試験体は製作後22ヶ月間経過しており, 床 版に乾燥収縮によると考えられる橋軸直角方向のひび 割れが認められた以外, 健全な状態であった. 床版コ ンクリートの圧縮強度および弾性係数については, 材 令37日における試験值であるが, 早強セメントを用い たコンクリートの一般的な性質から,材令 22 月にお いても大きな変化はないものと推定される.

$1 / 2$ 模型の試験体（図-1）を用いて, 主析損傷前後
表 -1 試験体諸元

\begin{tabular}{|c|c|c|}
\hline \multirow{3}{*}{$\begin{array}{c}\text { 上下 } \\
\text { フランジ }\end{array}$} & 板厚・材質 & $450 \times 19 \mathrm{~mm}(\mathrm{SM} 520 \mathrm{~B})$ \\
\hline & 降伏点 & $431 \mathrm{~N} / \mathrm{mm}^{2}$ \\
\hline & 引張強さ & $560 \mathrm{~N} / \mathrm{mm}^{2}$ \\
\hline \multirow{3}{*}{ ウェブ } & 板厚・材質 & $\begin{array}{l}1500 \times 10 \mathrm{~mm} \\
(\mathrm{SM} 520 \mathrm{~B})\end{array}$ \\
\hline & 降伏点 & $395 \mathrm{~N} / \mathrm{mm}^{2}$ \\
\hline & 引張強さ & $556 \mathrm{~N} / \mathrm{mm}^{2}$ \\
\hline \multicolumn{2}{|c|}{ 床版の圧縮強度（材令 37 日） } & $51.0 \mathrm{~N} / \mathrm{mm}^{2}$ \\
\hline \multicolumn{2}{|c|}{ 床版の弾性係数（材令 37 日） } & $3.24 \times 10^{5} \mathrm{~N} / \mathrm{mm}^{2}$ \\
\hline \multicolumn{2}{|c|}{ ハンチ高 } & $70 \mathrm{~mm}$ \\
\hline \multicolumn{2}{|c|}{$\begin{array}{c}\text { 合成桁としての中立軸位置 } \\
\text { (床版上縁からの距離) }\end{array}$} & 435. $\mathrm{mm}$ \\
\hline \multicolumn{2}{|c|}{$\begin{array}{l}\text { 合成桁としての降伏荷重 } \\
\text { (片主䘕上への集中荷重) }\end{array}$} & $361.5 \mathrm{tf}(3545 \mathrm{kN})$ \\
\hline
\end{tabular}

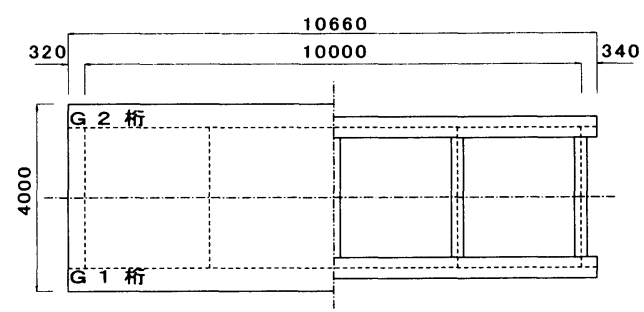

(a) 平面図

4000

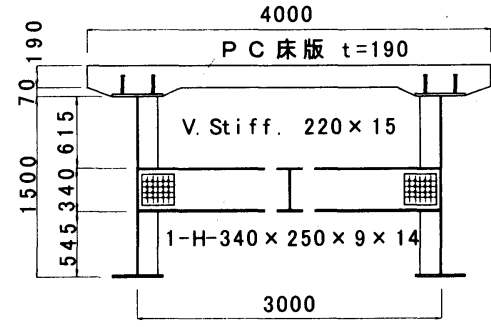

(b) 断面図

図 -1 試験体概要

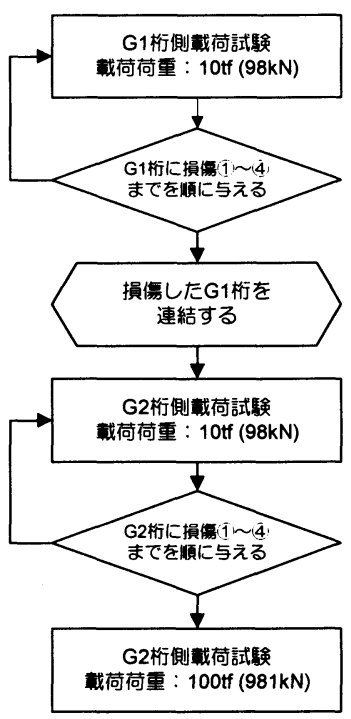

図-2 試験の流れ 


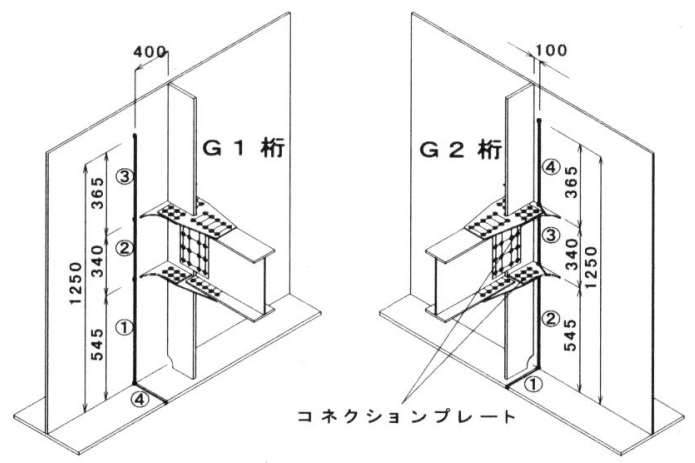

図-3 主桁損傷概要

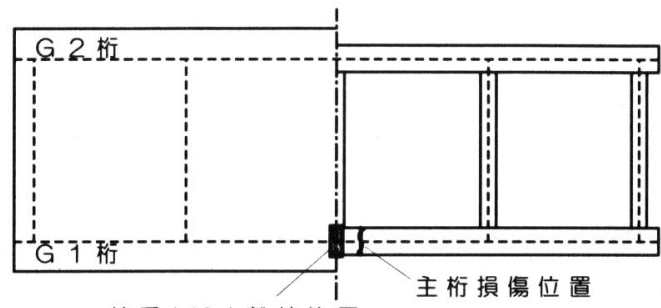

荷重（10t）載荷位置

（a) G1 桁側載荷試験

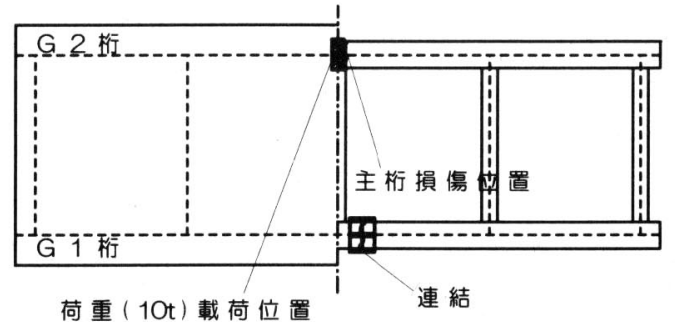

(b) G2 析側載荷試験

図-4 荷重載荷・主析損傷位置

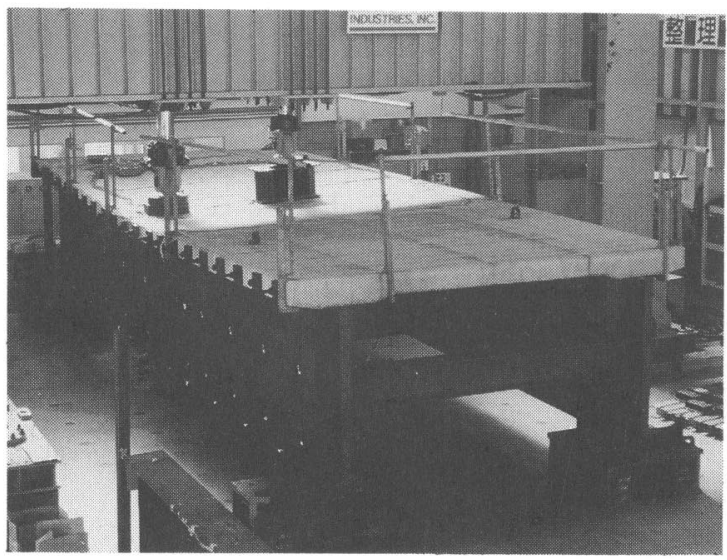

図-5 荷重載荷状態

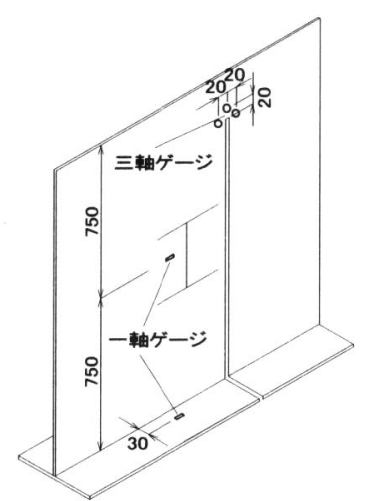

図 -6 ゲージ貼付位置

に図-2に示す流れで静的載荷試験を行った.下フラン ジ全断面と下端から合成桁中立軸までのウェブ断面に 対し, ガス切断を施して疑似クラックを生成し，これ を主析損傷とした（図-3）。ここで，主桁損傷を与え た位置は支間中央に近い位置であり, 本文では, 曲げ が卓越した断面の疲労亀裂の進行をシミュレートして, 損傷時の安全性を評価することを目的としている。

\section{（2）載荷方法}

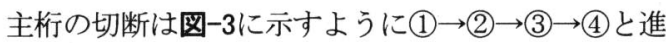
め, 損傷前の状態も含めて損傷ごとに順次 $10 \operatorname{tf}(98 \mathrm{kN})$ 荷重（載荷位置: 桁中央上）による載荷試験を行った (図-4). 荷重載荷状態を図-5に示寸. G1 桁側の載荷 試験が終了後, 切断した $\mathrm{G} 1$ 析を連結しG2桁側の載荷 試験・切断を同様に行った.ここで, G1桁の損傷は横 析継手部の溶接位置から発生するクラック(ウェブか ら損傷する)を, G2桁の損傷は下フランジと垂直補剛 材の溶接位置から発生するクラック(下フランジから 損傷する）を想定している.この 2 モードは今までの 疲労損傷事例から判断して決定したものである.すな わち,プレートガーダー橋で起こりうる損傷としては, 横析等を取り付けるためのウェブガセット端(JSSC疲 労設計指針》)によ $\mathrm{G}$ 等級) から疲労亀裂が発生する ケースと,垂直補剛材と主桁下フランジの間の溶接継 手 (JSSC疲労設計指針》によるE等級) から亀裂が発 生するケースである。

なお, G1桁の連結は損傷部の下フランジ, ウェブの 断面力が伝達できるように鋼板を配し，周囲をすみ肉 溶接寸る方法で行った.また, G2桁の損傷は横桁取り 付け部のコネクションプレートの切断も含むが, 試験 では損傷(3)をえた時に横桁のコネクションプレート の切断も同時に行った.

G2析損傷(4)の荷重 $10 \mathrm{tf}(98 \mathrm{kN})$ の載荷試験を行った後 に, 試験体の崩壊荷重を調べるために, 荷重 $100 \mathrm{tf}$ 
$(981 \mathrm{kN})$ までの載荷試験を行った。ここで荷重 $100 \mathrm{tf}$ $(981 \mathrm{kN})$ は, 使用したジャッキの最大載荷能力である.

なお,ひずみゲージは床版上縁・上下フランジ・ウェ ブ中央・横桁の他, 図-6に示すように主析の損傷ごと に切断クラックの先端部にも取付け, 応力の測定を 行った. 主桁のひずみゲージはスパン中央の他, 中央 より $1.25 \mathrm{~m}, 2.5 \mathrm{~m}$ の位置に取り付けた

\section{3. $10 t f(98 k N)$ 荷重载荷時の試験結果}

載荷荷重 $10 \mathrm{tf}(98 \mathrm{kN})$ の範囲内では, 残留たわみ, 残 留応力はほとんど生じず, 以下に示す試験結果は弾性 挙動範囲内における考察である.

\section{（1）主析たわみと全体挙功}

図-7, 図-8はそれぞれ G1 桁,G2 桁の主析損傷にと もなうたわみの変化を示している.

図-4(a)に示したG1桁を対象とした載荷試験では, 主 桁損傷をウェブから与えており, 損傷(1)〜(3)の状態で はほとんど挙動に変化はなく,損傷(4)で下フランジが 切断されると主析たわみは急激に増加した.すなわち, 損傷(1)〜(3)において,曲げが卓越する断面ではウェブ に断面欠損があっても桁としての機能が損なわれるこ とはない。

合成析と見なした場合の断面 2 次モーメントは $2.97 \times 10^{6} \mathrm{~cm}^{4}$, ウェブの断面欠損を孔引き断面と考慮し た場合の断面 2 次モーメントは $2.09 \times 10^{6} \mathrm{~cm}^{4}$ であり,主 桁中央部の孔引き断面では約 $30 \%$ の断面剛性が低下し ている.この影響がたわみの増加に寄与し, 計測值で は約12\%のたわみの増加であった

これと比較して，図-4(b)に示したG2析を対象とし た載荷試験では下フランジより損傷を与えており,損 傷(2)(下フランジおよびウェブ下端より $545 \mathrm{~mm}$ 高さま での損傷）までは主桁たわみの増大は小さいものの, 横杼取り付け部の上下のコネクションプレートの切断 に及ぶ損傷(3), 損傷(4)と進むにつれてたわみは大きく 増加した.コネクションプレートを切断した損傷(3か らたわみが急增したことから,コネクションプレート が主桁の曲げを伝達することことに寄与していたこと が推測された.損傷(4)まで進行させた結果, G1桁に損 傷を与えた場合のたわみとほぼ等しく,全体的な挙動 も同様であった。

図-9 は，G1 析を対象とした損傷(4)における 10tf $(98 \mathrm{kN})$ 荷重載荷時の各主柠たわみである.前出の図-7 からもわかるように主析損傷後のG1主桁たわみは損 傷前に比較して 6 倍程度に急増し, 主析損傷位置付近 でのたわみ変化に角折れが観察された。一方の損傷を

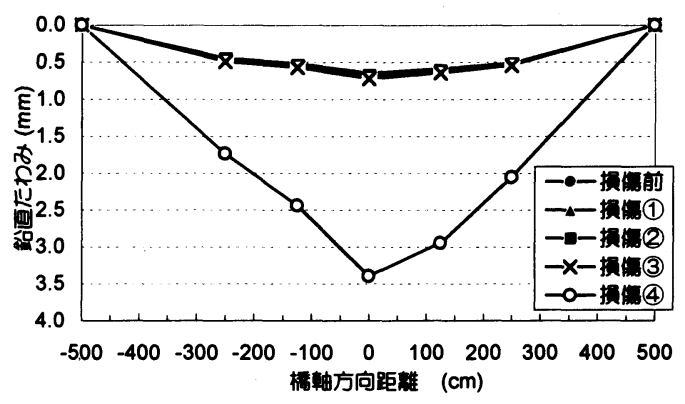

图-7 主桁たわみ（G1 桁側載荷試験）

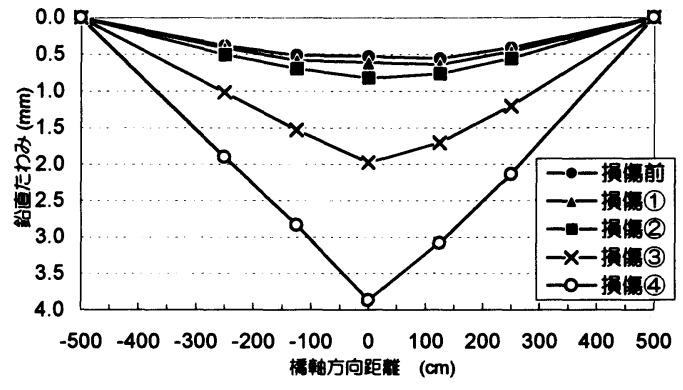

图 -8 主桁たわみ（G2 桁側載荷試験）

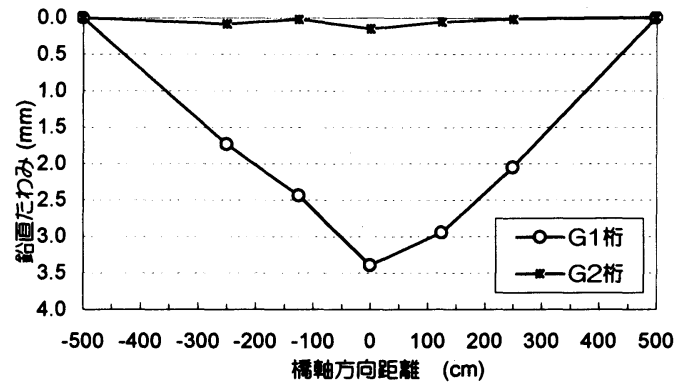

图-9 主桁たわみ（主桁損傷(4)）

受けていないG2主桁については, 主析損傷後のたわみ はほぼゼロであり,主杕損傷前後でたわみの変化は確 認されなかった.このことは, 損傷を受けた析の断面 力は, 床版や横桁を介して一方の桁にはほとんど伝達 されないことを示しており,主桁損傷によりG1桁から G2 桁への荷重分配が期待できないことは明らかであ る.このような変形に対して除荷時の残留たわみはほ とんど生じない状態であり(最大 $0.03 \mathrm{~mm}$ 程度), 変形 性状から判断すると損傷(4)の構造系は, 鋼桁損傷部が 曲げモーメントを伝達しないヒンジとして挙動する， 鋼析で補剛された床版橋とみなすことができると考え られる。

\section{（2）主析応力と铜析の举助}

図-10, 図-11 は 10tf $(98 \mathrm{kN})$ 荷重載荷時における主 桁損傷前および損傷(4)におけるG1桁の下フランジとウ 

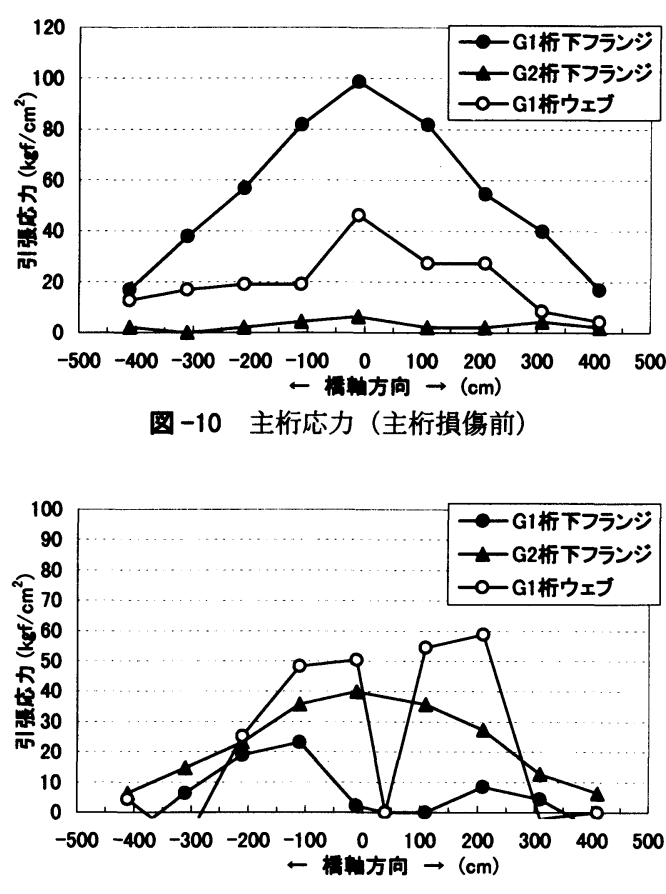

図-11 主桁応力（主标損傷(4)

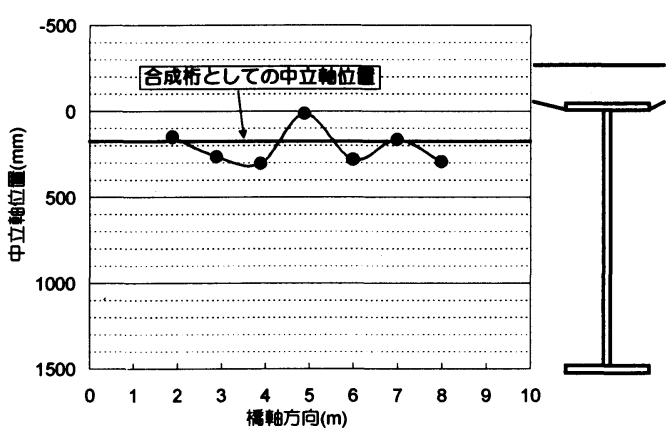

图-12 G1 析の中立軸位置（主析損傷前）

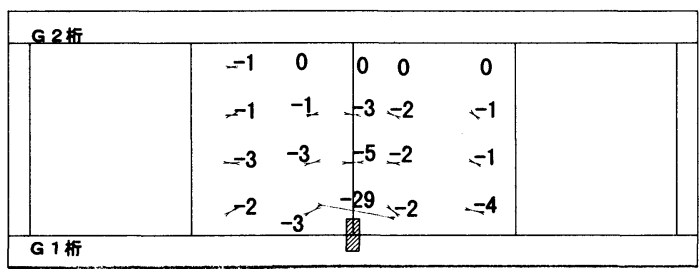

図-13 主析損傷前の床版上縁最小主応力 $\left(\mathrm{kgf} / \mathrm{cm}^{2}\right)$

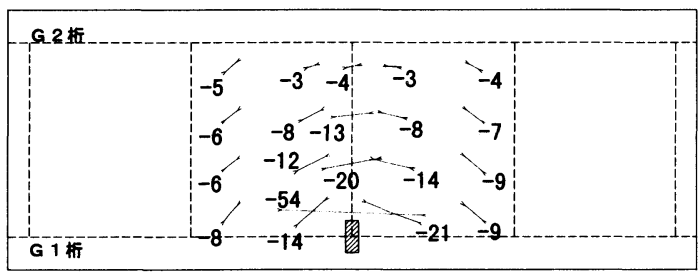

图-14 主桁損傷後の床版上縁最小主応力 $\left(\mathrm{kgf} / \mathrm{cm}^{2}\right)$
エブ応力, およびG2桁のフランジ応力である. 图-12 は同様に応力の測定值から算定した $\mathrm{G} 1$ 桁における中 立軸位置である．図-10，図-12 に示した損傷前の主 桁応力および中立軸は, 主桁中央で横桁取付け部の影 響を受けていると考えられるものの, 合成析としての 特徵的な挙動であると言える.一方，図一11に示した 損傷後は, 下フランジにおける引張応力分布から損傷 部をヒンジとした妳として挙動していることが伺え， ウェブの応力については損傷部付近で大きくなり,構 造系が上述したように変化していることに対応した挙 動と言える.

なお, 図-11において, 損傷を受けていないG2析の 下フランジ応力が, $\mathrm{G} 1$ 桁下フランジ損傷後に増加して いるのは, 後述の 5 章で示した F EM解析結果から, 橋軸直角方向の変位成分 (橋軸一鉛直平面に対する曲 げ)によるものと推定された.

\section{（3）床版上緑の応力分布と版の挙呩}

構造系が損傷前後で変化すると,床版の応力性状も 変化することが推測される.図-13,图-14は10tf (98kN) 荷重載荷時における主栴損傷前および損傷(4)時の床版 上縁の圧縮応力分布である. 図-13より，載荷点付近 の局部応力以外には床版上縁応力は小さく, 主応力は 橋軸方向に流れており,主桁損傷前の床版は桁の断面 の一部として挙動する傾向が強いことが確かめられた. 一方, 図-14に示す損傷(4)では, 最大 $54 \mathrm{kgf} / \mathrm{cm}^{2}(5.30 \mathrm{~N} /$ $\mathrm{mm}^{2}$ )の圧縮応力が確認され, その主応力方向から判断 すると,主桁たわみと全体挙動から推定されたように, 床版は主桁の一部として挙動するよりも,むしろ曲げ モーメントを伝達しない不連続点を有する弾性标で支 持された版として挙動する傾向の強いことが伺える.

\section{4. $100 t f(981 \mathrm{kN})$ 荷重臷荷時の試験結果}

G2妳損傷(4)の10tf(98kN)荷重の載荷試験を行った後 に，試験体の終局耐力を調べるために，荷重 $100 \mathrm{tf}(981 \mathrm{kN})$ までの載荷試験を行った.ここで荷重載荷

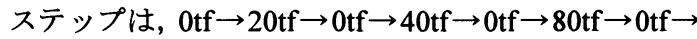
$100 \mathrm{tf} \rightarrow 0 \mathrm{tf}(0 \mathrm{~N} \rightarrow 196 \mathrm{kN} \rightarrow 0 \mathrm{~N} \rightarrow 392 \mathrm{kN} \rightarrow 0 \mathrm{~N} \rightarrow 785 \mathrm{kN} \rightarrow$ $0 \mathrm{~N} \rightarrow 981 \mathrm{kN} \rightarrow 0 \mathrm{~N})$ とした.

\section{(1) 主桁たわみと全体挙峌}

図-16に70tf $(686 \mathrm{kN})$ 荷重載荷時までの主析損傷後の 主析たわみを示す.ここで, 荷重70tf $(686 \mathrm{kN})$ 載荷以降 のたわみについては, 使用した変位計の能力から測定 不能となったため,データを示すことができなかった. 
損傷を受けていないG1析にたわみが生じていないの は, $10 \mathrm{tf}(98 \mathrm{kN})$ 荷重載荷時と同様の挙動である. 一方 のG2は, 損傷部がヒンジのように働くため, 前章で示 した考察から床版コンクリートが弾性範囲内であれば 主桁のたわみはこのヒンジの回転角で決定される.載 荷荷重12tf(117kN)を超えると疑似クラック先端部の局 部主ひずみが急激に増大し塑性域に入ったが, 載荷荷 重20tf (196kN)の除荷時の残留たわみはわずかであっ た.その後荷重40tf $(392 \mathrm{kN})$ まで載荷すると床版ひび割 れの発生が観察され, 除荷時には約7mmの残留たわみ が測定された. 再び載荷すると, 載荷荷重 $46 \mathrm{tf}(45 \mathrm{lkN})$ でガス切断による疑似クラックから新たなクラックの 発生が観察され, 荷重の増加に伴ってクラックは進展 を続けた. その後, 載荷荷重 $92.5 \mathrm{tf}(907 \mathrm{kN})$ で主析損傷 位置付近の床版上縁の一部に圧壊が生じ, ジャッキの 最大能力である $100 \mathrm{tf}(981 \mathrm{kN})$ までの載荷に試験体は耐 えた (図-15). 実際の崩壊荷重はこれ以上あることが 期待できるものの, ジャッキの荷重およびストローク の指示值より, 床版に圧壊が認められた載荷荷重 $92.5 \mathrm{tf}$ $(907 \mathrm{kN})$ 以降はたわみが急増したことから, 構造物とし ての機能を失うのはこの荷重 (以降, この荷重を終局 耐力という) とみなしてよいと判断された.つまり，1/ 2スケールの試験体では片側の主桁が切断された状態 の終局耐力は92.5tf $(907 \mathrm{kN})$ である.

\section{（2）鋼桁クラックの性状}

ガス切断による主桁損傷部の先端から発生したク ラックは, 上述したように荷重46tf $(45 \mathrm{lkN})$ 時から目視 で観察され, 載荷荷重 $100 \mathrm{tf}(981 \mathrm{kN})$ では約 $11 \mathrm{~cm}$ に進展 した. 図-17に載荷試験終了後のクラックの状況を示 す.クラックの進展モードは, 開口形と面外せん断形 の混合変形である.これは, 開断面椼でねじりモーメ ントが作用して断面が回転変形しようとする時, G2析 の損傷部を境にして荷重が載荷されている析側と載荷 されていない桁側では面外変形量が異り,クラック先 端は橋軸直角方向のせん断応力が作用し,このせん断 応力と橋軸方向の曲げによる直応力が同時に作用する ためであると考えられる。

クラックの進展は鋼材のじん性が関係する.試験体 に使用したウエブ鋼材の材質はSM520Bであり, 本試 験におけるクラックの進展状況は, B 材としての規定 值である $0{ }^{\circ} \mathrm{CV}$ ノッチシャルピー值 $2.8 \mathrm{kgf} \cdot \mathrm{m}(27 \mathrm{kN}$ ・ $\mathrm{mm})$ 以上が保証されている鋼材の場合である.じん性 值が低い鋼材では脆性破壊を生じる可能性があり,こ れについては鋼材の材質からの検討が必要である.

\section{(3) 2 主桁の崩壊機構}

図-18，図-19はそれぞれ 100tf $(981 \mathrm{kN})$ 載荷試験後

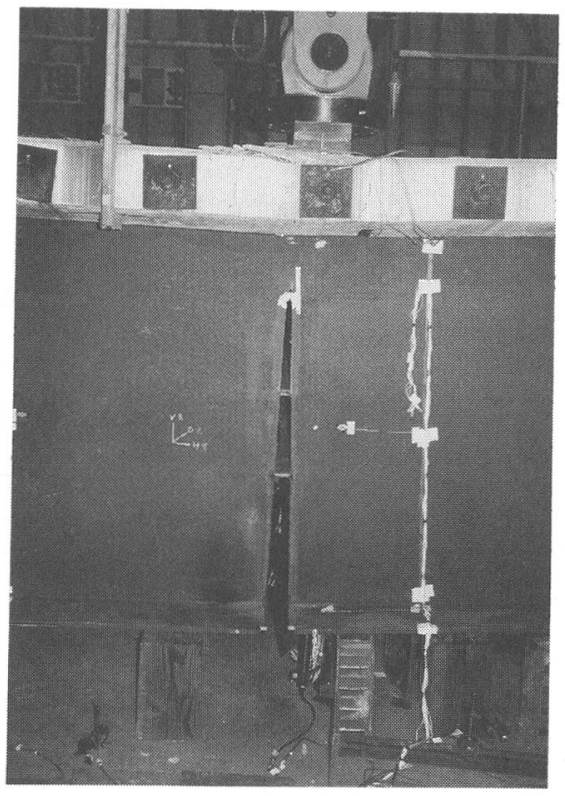

図-15 試験体の挙動

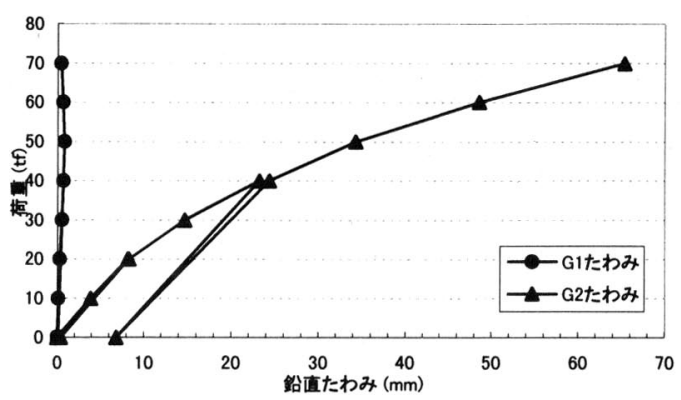

図-16 70tf 荷重載荷までの主桁たわみ
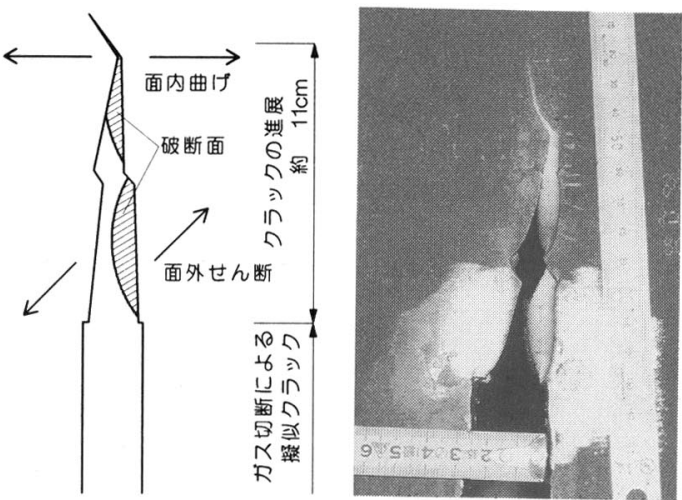

図-17 クラックの進展

に観察した床版上下面のひび割れ状況である１0 $10 \mathrm{ff}$ $(98 \mathrm{kN})$ 載荷試験時にも前述の床版上縁応力から確認し たように, 損傷後の試験体は床版と主桁の桁作用より も版として挙動する傾向が強いことがわかる. 


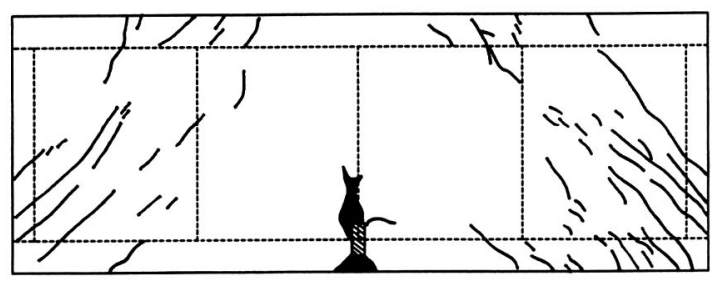

図-18 床版上面のひび割れ状況

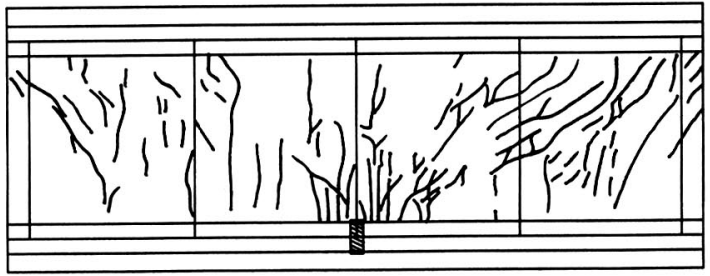

図-19 床版下面のひび割れ状況

ひび割れ状況も対応した傾向であることを示してお り, 横構を配置しない 2 主桁橋で曲げが卓越する断面 の主桁損傷を対象とした載荷試験の結果から,フラン ジとウエブを切断した 2 主析橋は, 曲げモーメントを 伝達しない不連続点を有する弾性桁で支持された床版 とみなすことができ, 終局耐力は損傷部付近の床版の 圧壊で決定されることがわかった. なお, 終局耐力の 予測については次章で考察を行う。

\section{FEM 解析によるシミュレーションと終局耐カ}

損傷を受けた 2 主析橋の終局耐力を解析的に評価し ようとすれば, 前章の載荷試験で解明された挙動を表 現できる解析モデルが必要である.前記したように損 傷を受けた 2 主桁橋は曲げモーメントを伝達しない不 連続点を有する弾性桁で支持された床版とみなすこと ができる.本章ではこの状態をシミュレートするため に, G2桁側の載荷試験に関して, 主桁損傷前および損 傷(4)時のモデルを作成し，MSC-NASTRANを用いて FEM立体解析を行い, 終局耐力の予測を試みた。

\section{(1) 解析モデル}

解析モデルは, 床版部を 8 節点のソリッド要素, 鋼 桁部を 4 節点のシェル要素, 床版と鋼桁は完全合成と して作成した.概要図を図-20に示す(解析モデルA). このモデルとは別に, 床版応力で終局耐力が決定され ることから,解析モデルの簡便さを図ることを目的に, 床版応力に着目したモデルを考えた.このモデルは床 版部をシェル要素,鋼析部をはり要素としており床版

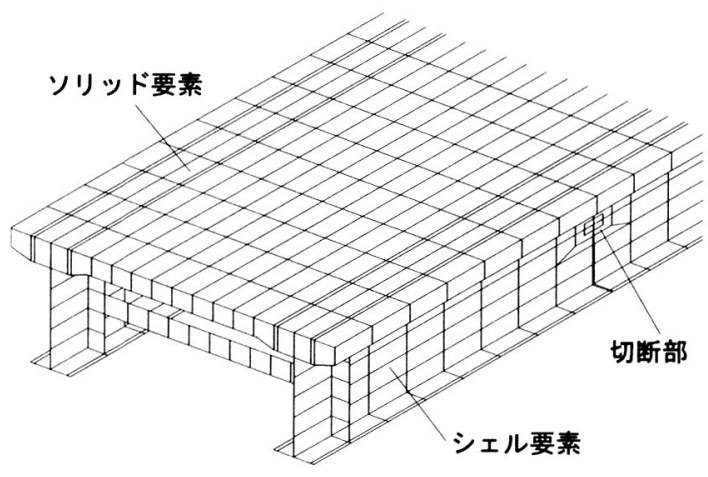

図 -20 解析モデル A 概要

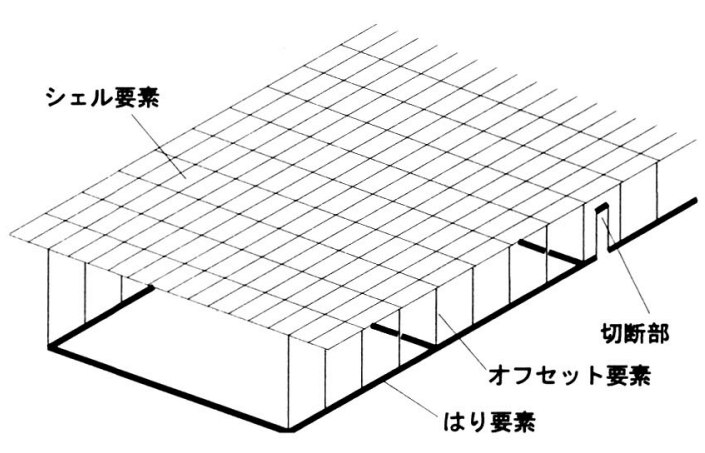

図-21 解析モデル B 概要

と鋼析は完全合成されているものとして,合成には剛 体 (オフセット要素) を用いた. 床版は橋軸直角方向 にプレストレスが導入された 1 方向 P C版であり,こ こでは等方性版として取り扱った.はり要素は $2 つ の$ 垂直方向に対する曲げ剛性とせん断剛性をもつ.また,

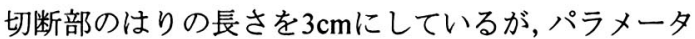
解析によりはりの長さの影響が少ないことを確認して いる. 解析モデルの概要図を図-21に示す（解析モデ ルB).

\section{（2）解析結果}

\section{a) 解析モデルA}

図-22, 図-23および図-24に解析モデルAによる 解析結果を示寸. 橋軸方向の引張応力は, 主桁損傷部 の先端で発生する局部応力からウェブー下フランジへ と伝達される.このことは試験結果の挙動 (下フラン ジ切断後には構造系が変化し, ウェブの応力が損傷部 付近で大きくなった）と一致している.またG1桁（損 傷を受けていない析）下フランジでの応力分布からも， 橋軸一鉛直平面に対する面外曲げの影響をうけて橋軸 直角方向の変位が生じていることは明らかであり,解 析結果の挙動が試験結果に等しいことがわかる. 


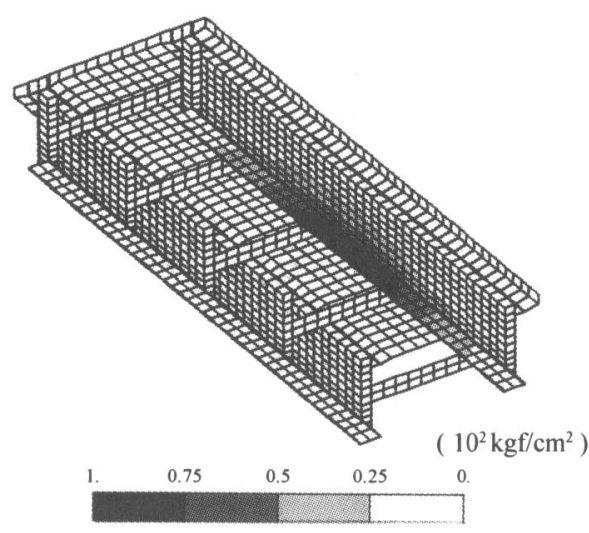

(a) 主桁損傷前

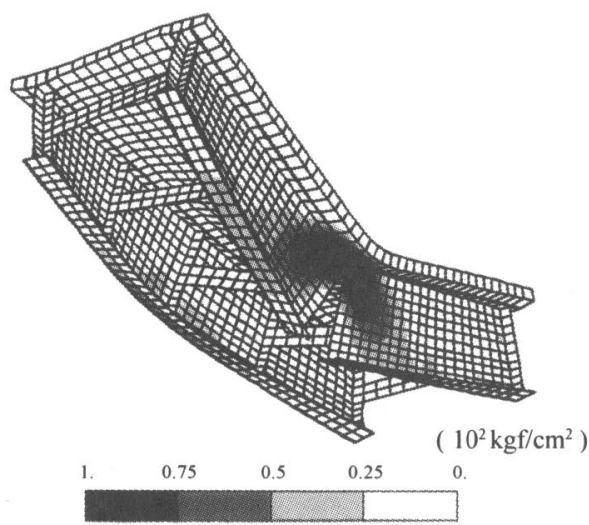

(b) 主析損傷(4)

図-22 橋軸方向引張応力

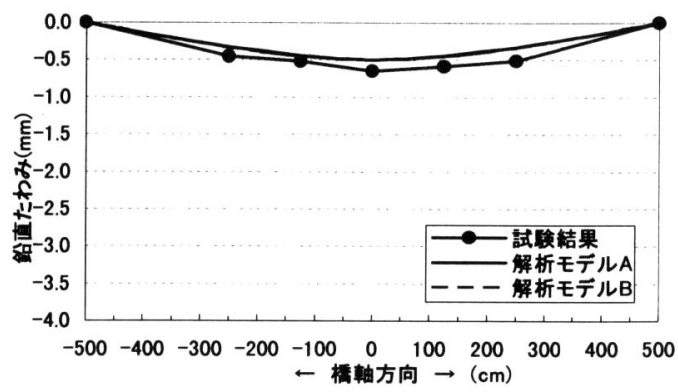

図-23主桁たわみ（主桁損傷前）

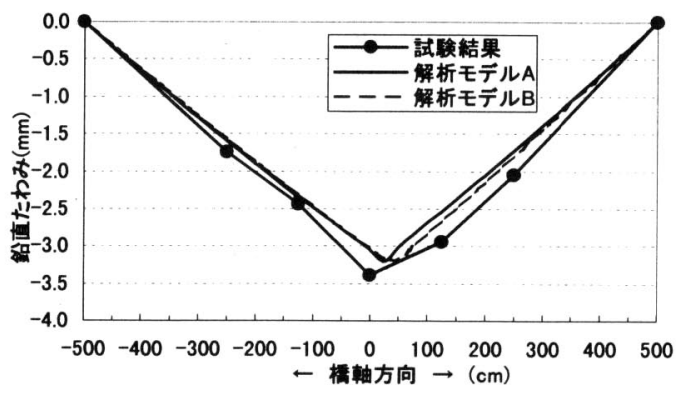

图-24主桁たわみ（主桁損傷(4)）
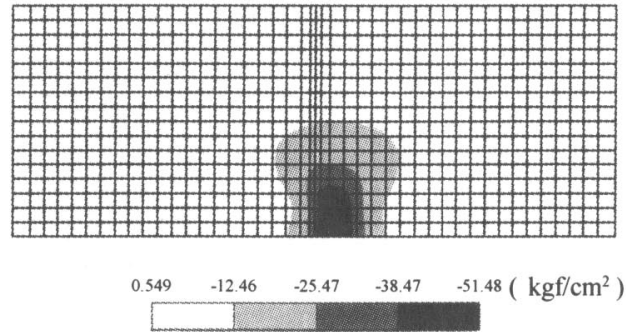

(a) 主标損傷前
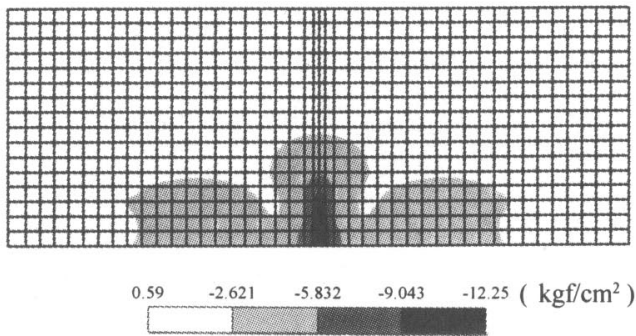

(b) 主析損傷(4)

图-25 床版上縁応力

主析たわみは解析值, 試験值でほぼ一致しており曲 げ剛性を適切に評価できていることが確認できた。

また, 図一22より主桁損傷前・後の変形挙動に着目 してみると, 主桁損傷後にはねじりモーメントが作用 して断面全体の回転変形が顕著化する.試験結果から, $\mathrm{G} 2$ 桁損傷後に $\mathrm{G} 1$ 桁下フランジの応力が増加しており, これが橋軸直角方向の変位成分によると推測されるこ とを前述したが, 解析結果よりこの推論が妥当である ことを確認した。

\section{b）解析モデルB}

図 -23，図-24 および図-25に解析モデルBによる 解析結果を示す. 主桁たわみについてはモデル A, B ともに同様の挙動を示し, 床版上縁の圧縮応力度 $51.5 \mathrm{kgf} / \mathrm{cm}^{2}\left(5.05 \mathrm{~N} / \mathrm{mm}^{2}\right)$ は試験值 $54 \mathrm{kgf} / \mathrm{cm}^{2}\left(5.30 \mathrm{~N} / \mathrm{mm}^{2}\right)$ にほぼ一致する結果を得た。

\section{(3) 終局耐力}

前章で示したように試験結果から 2 主桁の終局耐力 は損傷部付近の圧壊で決定されることが分かっている. 設計上の安全性を判断する上では, 解析においてコン クリートを完全弾塑性体であると仮定し, 床版上縁応 カがコンクリート強度に達する荷重が終局耐力点と見 なしても良いであろうと考えられる.これは力のつり 合い状態の中で, 要素における材料が降伏点に達した ときの荷重で耐力を評価する極限解析の下限定理に対 応し, 耐力の下限值を与えるものである ${ }^{8}$. 極限解析の 上限定理や, F EM弾塑性解析により耐力を評価する 方法も適用が可能であるうが, 極限解析の下限定理に 


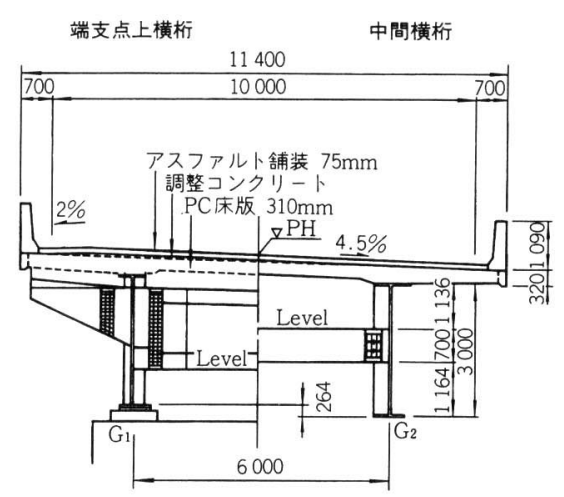

図-26 ホロナイ川橋断面

表-2 各モデルの断面（支間中央部）

\begin{tabular}{ccc}
\hline 支間長 & 上下フランジ断面 & ウェブ断面 \\
\hline \hline $40 \mathrm{~m}$ & $66 \times 3.1 \mathrm{~cm}$ & $300 \times 1.5 \mathrm{~cm}$ \\
$50 \mathrm{~m}$ & $83 \times 4.0 \mathrm{~cm}$ & $300 \times 1.5 \mathrm{~cm}$ \\
$60 \mathrm{~m}$ & $98 \times 4.8 \mathrm{~cm}$ & $300 \times 1.5 \mathrm{~cm}$ \\
$70 \mathrm{~m}$ & $100 \times 6.1 \mathrm{~cm}$ & $300 \times 1.8 \mathrm{~cm}$ \\
\hline
\end{tabular}

表-3 解放モーメントによる最大たわみ

\begin{tabular}{cc}
\hline 支間長 & たわみ $(\mathrm{cm})$ \\
\hline \hline $40 \mathrm{~m}$ & 5.0 \\
$50 \mathrm{~m}$ & 8.9 \\
$60 \mathrm{~m}$ & 14.0 \\
$70 \mathrm{~m}$ & 19.9 \\
\hline
\end{tabular}

よって求めた耐力は設計上安全側の評価になり, 次章 で示寸実橋における安全性の評価を行う上では, 有意 義な評価方法であると言える.

以上の評価方法でコンクリートの圧縮強度が材令 22ヶ月においても $51.0 \mathrm{~N} / \mathrm{mm}^{2}\left(520 \mathrm{kgf} / \mathrm{cm}^{2}\right)$ であると仮定 すれば, 終局耐力は容易に推測することができ, $10 \mathrm{tf} x$ $520 / 51.5=101.0 \mathrm{tf}(991 \mathrm{kN})$ となる.実測值は92.5tf $(907 \mathrm{kN})$ であり,解析值の方が若干高い傾向であった。

次章で示寸実橋における安全性の評価は, 解析の簡 便さから解析モデルBを用いて検討を行うことにする.

\section{6. 実橋における安全性の評価}

\section{(1) 対象橋梁モデル}

本研究で対象とした損傷は,曲げが卓越した断面の 横桁取付部からの疲労損傷であり, 実橋を対象に, 前 述した解析モデル Bを用い, 床版に発生する応力から

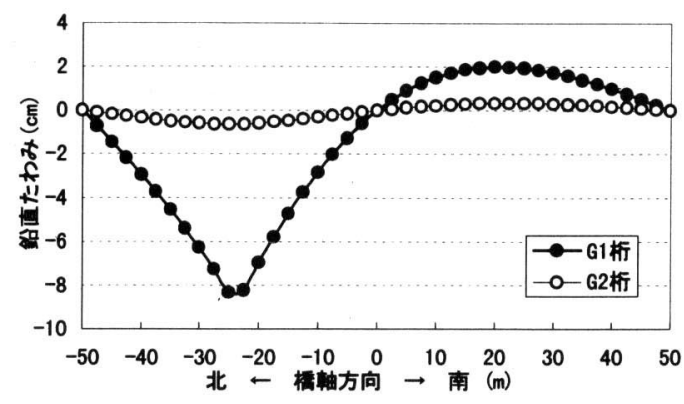

図-27 主桁たわみ（支間 $50 \mathrm{~m} ・$ 解放モーメント荷重）

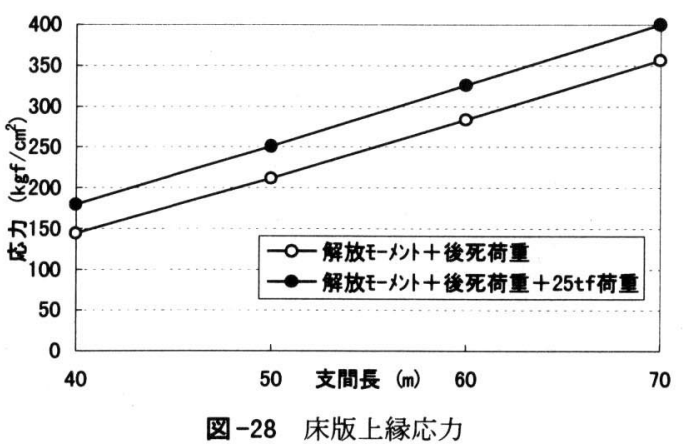

実橋における安全性の検討を行った.実橋サイズで解 析を行うにあたり，対象とした橋梁は，支間長 $40 \mathrm{~m}$, $50 \mathrm{~m}, 60 \mathrm{~m}, 70 \mathrm{~m}$ を有する 2 径間連続 2 主桁橋であり, ホ ロナイ川橋断面 (図-26参照) を参考に総幅員: $11.4 \mathrm{~m}$, 床版厚: $31 \mathrm{~cm}$, 主桁間隔: $6.0 \mathrm{~m}$ の非合成桁として試設 計を行い断面を決定した橋梁である.断面諸元を表-2 に示す.ここで，2径間連続桁を対象にしたのは，多 径間に比べ主桁損傷を与えた場合に不利になるからで ある.またここで非合成桁として鋼桁断面を決定した が, 解析モデルBを用いるにあたり, 床版と鋼桁との 合成は保証されているものとしヤング係数比 $\mathrm{n}=7$ とし て, 後死荷重および活荷重に対しては合成挙動を示す ものとした。

\section{（2）解析方法}

実橋モデルでの解析では, 主桁損傷部は曲げに対し て最も危険な状態である支間中央部に与え, 下フラン ジおよびウェブ上端までのひび割れが進展した主桁損 傷を想定した.損傷部の床版上縁応力を算出するにあ たり, 次の 3 ステップの解析を行った。

\section{a）ステップ1 主标損倠前の状態}

ステップ 1 は, 主析損傷前に鋼桁に発生する断面力 を表現するための解析である.まず, 主桁のはり要素の みをモデル化し, 主桁および床版重量を作用させ, その 後, 床版をシェル要素でモデル化してはり要素とオフ セット要素で連結した解析モデルBの状態に後死荷重を 
作用させた.

\section{b）ステップ 2 主析損儌による断面力の変化}

ステップ 1 の死荷重によって桁に生じる曲げモーメ ントに対して,主桁の支間中央に損傷を受けることに よって,この位置の曲げモーメントが解放されること になる.この曲げモーメントの解放は, 解析モデル B の状態で, ステップ 1 の解析における支間中央部のは り要素に生じた曲げモーメントを逆方向に載荷するこ とにより表現した.ここで, 解放モーメントによって 損傷位置に生じる最大たわみを表-2に, 支間 $50 \mathrm{~m}$ の場 合におけるたわみ分布を図-27に示す.

主析損傷後の状態は, ステップ 1 における解析結果 と解放モーメントによる解析結果とを加え合わせるこ とにより表現した. 主析損傷後の状態の一部として, 主桁損傷部の床版上縁応力度を, 後述するステップ 3 の解析結果とともに図-28に示す.

\section{c）ステップ 3 主析損伤後のトラック載荷}

参考データとして, 主析損傷後に $25 \mathrm{tf}(245 \mathrm{kN})$ トラッ ク走行時を想定し, 解析モデル B の状態で支間中央部 の主桁損傷部に25tf $(245 \mathrm{kN})$ の荷重を載荷して解析を 行った.

\section{（3）実橋における安全性の評価}

載荷試験結果から, 主析に損傷を受けた 2 主析橋の 構造物としての機能を失う終局耐力は, 床版部の圧縮 応力で決定されることを 4 章で示した. 図-28に示し た損傷時の床版上縁応力度から, 支間長と床版応力度 がほぼ線形の関係であり, ステップ 2 の状態で支間長 $70 \mathrm{~m}$ で約 $360 \mathrm{kgf} / \mathrm{cm}^{2}\left(35.3 \mathrm{~N} / \mathrm{mm}^{2}\right)$ の床版応力度が発生し, ステップ 3 の $25 \mathrm{tf}(245 \mathrm{kN})$ の荷重により約 $40 \mathrm{kgf} / \mathrm{cm}^{2}$ $\left(3.92 \mathrm{~N} / \mathrm{mm}^{2}\right)$ の床版応力度が増加する解析結果であっ た. 本検討では非合成桁を対象にしたが, ステップ 2 の解放モーメント量については, 合成桁を対象とした 場合でもほぼ同じであり，图-28に示すステップ 2 の 解放モーメントにより生じる床版応力度は合成桁を対 象とした場合も同じであると思われる.P C 床版 2 主 桁橋の設計マニュアル(案)9では床版コンクリートの 設計基準強度を $400 \mathrm{kgf} / \mathrm{cm}^{2}\left(40 \mathrm{~N} / \mathrm{mm}^{2}\right)$ で規定しており, この設計基準強度と比較すると, 支間長 $70 \mathrm{~m}$ 程度まで は, 主桁損傷が生じても 2 主桁橋の終局耐力に至らな いことが推定された. 実橋における維持管理から, 下 フランジおよびウェブ上端までのひび割れが進展した 状態にまで放置することは考え難いが,このような状 態を想定しても, 床版の健全性と鋼析との合成が保証 されていれば「2主桁橋は危険な橋ではない」と言え る.ただし，表-2および図-27に示した損傷時のたわ みの変化からは, 損傷部で大きな角折れを生じ, 支間 長70mでは $19.9 \mathrm{~cm}$ もたわみ変化が生じ, この状態で
すぐには落橋には結びつかないものの, 橋梁としての 使用性に支障をきたすことは明らかである.

\section{7. まとめ}

本研究で対象とした橋梁の前提条件として「下横構 を省略した 2 主桁橋」,「健全な床版」,「床版と鋼桁と の合成が保証されていること」が挙げられる.以下に, 1/2スケール模型を利用し, 曲げが卓越した断面の横桁 取付部からの疲労損傷を想定して, 主析に損傷を与え 載荷試験を実施した結果, およびF EMによる解析的 な検討を行った結果をまとめる.

(1) 主析の切断がウェブのみに留まっている状態では 全体挙動の変化は小さく,その影響はウェブの断面 欠損による主桁の剛性低下とみなされる.一方, 損 傷がウェブと下フランジの切断に及ぶと,たわみ, 損傷位置近傍の応力は急増した。

(2)この主析損傷時の状態は, 鋼析部が曲げモーメン トを伝達しないヒンジとして挙動し,床版は不連続 点を有する弾性析で支持された版として挙動すると 考えられた。

(3) 1/2スケール模型では, 片側の主标が切断された 状態で, 2 主析橋として機能を失う終局荷重は損傷 付近の床版コンクリートの圧壊で決まり,その時の 荷重は92.5tf(907kN)であった。

(4) F E M解析で損傷を受けた 2 主析橋の挙動を表現 でき,損傷付近の床版に発生する応力を解析的に求 めることができた.この解析モデルに極限解析の下 限定理を適用すれば, 終局荷重が予測できることが 確かめられた。

（5）実橋における2主桁橋の安全性について, 上記解 析モデルを用いて考察を行うと,有効幅員 $10 \mathrm{~m}$ 程度 の連続 2 主析橋で支間 $70 \mathrm{~m}$ 程度以下であれば, 主桁 が切断された状態で床版に発生する応力度はコンク リート強度以下であり, 2 主桁橋の終局耐力には至 らないことが推定された。

以上のように, 2 主析橋を複合構造とみなして安全 性の評価を行うと, 決して危険な橋ではないと言える. 検討結果は, 2 主桁橋を考える上で床版は極めて重要 な部材であり, 残存耐力の観点からも床版は「壊れな い半永久的な構造部材として捉える必要があること を改めて示された結果であった。

\section{参考文献}

1) 高橋昭一, 志村勉, 橘吉宏, 水野浩：P C 床版 2 主I标 橋による合理化検討, 土木学会第 49 回年次学術講演会 
講演概要集 I , pp.268-269, 1994.

2) Idriss,R.I., White,K.R., Woodward,C.B. and Jaauregui,D.V.: After-Fracture Redundancy of Two-Girder Bridge:Testing I40 Bridge over Rio Grande, Proc. Fourth International Bridge Engineering Conference, TRB, NRC, pp.316-326, 1995.

3) 高橋昭一, 志村勉, 橘吉宏, 小西哲司: P C 床版 2 主桁 橋「ホロナイ川橋」の設計および解析・試験検討, 橋 梁と基礎, Vol.30, No.2, pp.23-30, 1996.

4) 高橋昭一, 橘吉宏, 志村勉, 森下弘行, 伊藤博章, 三木 千壽:少数主桁橋の横桁取付構造に関する実験的検討, 土木学会論文集, No.570 / I-40, pp.107-108, 1997.

5) 高橋昭一, 鈴木隆, 橘吉宏, 志村勉, 伊藤博章, 三木千 壽: $1 / 2$ スケール模型を用いた 2 主桁橋の立体挙動に関 する実験的研究, 土木学会第 50 回年次学術講演会講演
概要集 I, pp.584-585, 1995.

6) 高橋昭一, 橘吉宏, 志村勉, 伊藤博章 : 水平荷重に対す る 2 主桁橋ホロナイ川橋の構造検討, 土木学会第 3 回 合成構造の活用に関するシンポジウム講演論文集, pp.19-23， 1995.

7) 日本鋼構造協会 : 鋼構造物の疲労設計指針・同解説, 1993.

8) Chen,W.F. : Plasticity in Reinforced Concrete, McGrow Hill, 1982.

9) 高速道路技術センター：平成 9 年度 P C 床版 2 主桁橋 の最適化に関する技術検討報告書, 1998 .

(1999.1.5 受付)

\title{
A STUDY OF AFTER-FRACTURE REDUNDANCY FOR TWO-GIRDER BRIDGES
}

\author{
Yoshihiro TACHIBANA, Manabu TSUJIKADO, Shigeru ECHIGO, \\ Shoichi TAKAHASHI and Chitoshi MIKI
}

Due to the structural features, two-girder bridges are considered to be at a higher risk to collapse if one of the main girders is damaged. However, it is hard to conclude that two-girder bridges with high stiffness P.C. (Pre-stressed Concrete) deck slabs do not possess redundant strength even after the damage is observed on the main girder. To understand the collapse mechanism and to assess the response behavior of the structure after damage was introduced, loading tests were conducted on the 1:2 scale model with the fractured main girder. Test results were utilized to assess the collapse mechanism and safety of two girder bridges was also evaluated by analyzing the data with the finite element method (F.E.M.) 